\title{
In Vitro Dissolution Study and Assay of Diclofenac Sodium from Marketed Solid Dosage form in Bangladesh
}

Tania Sultana ${ }^{1,2}$, Md. Didaruzzaman Sohel ${ }^{1,2 *}$, Md. Hassan Kawsar ${ }^{1}$ and Rebecca Banoo ${ }^{3}$

${ }^{1}$ Department of Pharmacy, State University of Bangladesh, Dhaka, Bangladesh

${ }^{2}$ Incepta Pharmaceuticals Ltd., Dhaka, Bangladesh

${ }^{3}$ Department of Pharmaceutical Chemistry, Faculty of Pharmacy, University of Dhaka, Dhaka, Bangladesh

\begin{abstract}
The aim of this study is to determine the potency of drug available in our market in Bangladesh. Diclofenac Sodium is a potent Non-Steroidal Anti-Inflammatory Drug (NSAID) and that are widely used and it is an Over the Counter (OTC) drug in Bangladesh. Potency determination was performed to evaluate that the marketed sample comply with the declared specification or not. In vitro Dissolution study was performed to see that if potency is high but the drug is not bioavailable. Hardness is also checked to see that whether it interfere with the dissolution which ultimately effect the bioavailability. In this present study a simple, cost effective and spectrophotometric method for the potency determination of marketed Diclofenac Sodium tablets is used. Four samples were randomly collected from the market and coded as D01, D02, D03 and D04 and the potency determined are $99.30 \%, 103.38 \%, 98.22 \%$ and $102.16 \%$ respectively. Hardness and in vitro dissolution of the above four brands of Diclofenac Sodium tablets were also studied and reported in the paper. After $1 \mathrm{~h}$ Dissolution release of DO1, D02, D03 and D04 are 94.16\%, $93.97 \%, 96.94 \%$ and $98.5 \%$ respectively. From all of the studies it seems that the samples were collected complies with the BP and USP requirements.
\end{abstract}

Keywords: In vitro; NSAID; Diclofenac sodium; Spectroscopic; Release kinetics; Bangladesh

\section{Introduction}

Diclofenac Sodium is sodium salt of [o-(2, 6-dichloro aniline) phenyl] acetate and is a potent Non-Steroidal Anti-Inflammatory Drug (NSAID) [1]. DS or sodium 2-[(2,6-dichlorophenyl)amino]phenylacetate, is a broadly used non-steroidal anti-inflammatory drug for the treatment of inflammatory conditions such as rheumatoid arthritis, osteoarthritis and ankylosing spondylitis [2]. NSAIDs are agents having anti-inflammatory, analgesic and antipyretic effects. These drugs are used frequently and commonly in humans as well as in animals to manage pain, fever and inflammation for the treatment of different clinical conditions such as rheumatic disorders, musculoskeletal disorders, sports injuries, muscular cramps and other syndromes involving pain and inflammation. Its pharmacological effects are believed to be due to blocking the conversion of arachidonic acid to prostaglandins by inhibiting cyclo-oxygenase enzymes. Diclofenac Sodium is almost completely absorbed after oral administration. However, due to its first pass metabolism, only about $50 \%$ of the absorbed dose is systematically available. The half-life of Diclofenac Sodium in plasma varies from 1-3 $\mathrm{h}$, with mean peak plasma levels of approximately $0.5 \mu \mathrm{g} / \mathrm{ml}$ and $1.0 \mu \mathrm{g} / \mathrm{ml}$ occurring after about $2 \mathrm{~h}$ after a single dose of $25 \mathrm{mg}$ and $50 \mathrm{mg}$ of enteric coated tablets respectively. About $99 \%$ of the drug is bound to human plasma proteins, mainly albumin [3]. It is $99 \%$ bound to human serum proteins. It diffuses into and out of synovial fluid. It is eliminated through urinary and biliary excretion of the glucuronide and the sulphate conjugates of the metabolite. Diclofenac Sodium has little anti-microbial activity and is under investigation for the treatment of tuberculosis. This is also used to treat chronic pain associated with cancer. It may prevent the development of Alzheimer disease if given daily in small doses for many years. Diclofenac Sodium also acts as antiuricosuric agent. Dosage form testing, development of the improved dosage form and determination of drug in biological samples is required in pharmaceutical industry and in research [4]. It is available in the various formulations such as injections, tablets, gel, suppositories and powdered form (Figure 1) [5,6].



Figure 1: Chemical structure of Diclofenac Sodium [6].

Diclofenac Sodium is not recommended for children less than 18 months of age, and only when essential in pregnant or lactating women [7] Solid dosage form like as Tablet is the most popular dosage form existing today because of its convenience of self-administration, compactness and easy manufacturing; sometimes immediate onset of action. Patient compliance, high-precision dosing, and manufacturing efficiency make tablets the solid dosage form of choice [8]. Diclofenac Sodium that is effective in the management of mild-to moderate postoperative pain. Their opioid sparing effect and availability in parenteral forms make

${ }^{*}$ Corresponding author: Md. Didaruzzaman Sohel, Department of Pharmacy, State University of Bangladesh, Dhaka, Bangladesh, Tel: +8801916016974; E-mail: sohelphr15@gmail.com

Received April 01, 2017; Accepted April 26, 2017; Published May 05, 2017

Citation: Sultana T, Sohel MD, Kawsar MH, Banoo R (2017) In Vitro Dissolution Study and Assay of Diclofenac Sodium from Marketed Solid Dosage form in Bangladesh. J Bioanal Biomed 9: 118-122. doi:10.4172/1948-593X.1000164

Copyright: @ 2017 Sultana T, et al. This is an open-access article distributed under the terms of the Creative Commons Attribution License, which permits unrestricted use, distribution, and reproduction in any medium, provided the original author and source are credited. 
them ideal for day-only and short-stay admissions for elective surgery [9-12]. The rational for their use is that they produce inhibition of peripheral hyperalgesia mediated by their anti-inflammatory properties 13, possibly supplemented by centrally mediated actions that attenuate central sensitization [13-17]. Available drugs in Bangladeshi market are Aceclofenac, Dexibuprofen, Dexketoprofen, Diclofenac diethyl ammonium salt, Diclofenac free acid, Diclofenac potassium, Diclofenac sodium, Diclofenac Sodium+Misoprostol, Etodolac, Naproxen, etc. [18].

\section{Materials and Methods}

All chemicals and reagents were used for potency studies were of analytical grade. Standard Diclofenac Sodium sample (assay 99.54\%) was given from Drug International Limited as a gift.

Collection of Samples: Four brands of marketed (production date not more than three month ago from the time of purchase) Diclofenac Sodium tablets were obtained from various drug stores. Samples were properly checked for their, Manufacturer name, Physical appearance, and Batch number, Date of manufacturing and Expiry date before purchasing [19]. They were randomly coded, such as D01, D02, D03 and D04. The labeled active ingredient of Diclofenac Sodium was $50 \mathrm{mg}$ and packaged in strip or in blister.

\section{Equipment's used}

A double beam Shimadzu UV-visible spectrometer (UV mini1700, Shimadzu Corporation, Kyoto, Japan with $1 \mathrm{~cm}$ quartz cells), HANNA HI 2211 PH meter ( Romania), Automated eight basket tablet dissolution tester UDP-80 USP Standard (Veego, India), Electronic balance AL 204 (Mettler Toledo, Japan), Hot air oven Labtech (Daihan, Korea) and Hardness Tester (Veego, India).

\section{Preparation of standard solution of diclofenac sodium}

$10 \mathrm{mg}$ of Standard Diclofenac Sodium powder (99.54\% pure) was dissolved in $5 \mathrm{ml}$ of Milli-Q water in a $10 \mathrm{ml}$ volumetric flask then add volume upto mark with Milli-Q water. Then $1 \mathrm{ml}$ of this solution was diluted to $50 \mathrm{ml}$ by adding Milli-Q water. The concentration of this solution was $20 \mu \mathrm{g} / \mathrm{ml}$.

\section{Determination of $\lambda_{\text {max }}$}

The above solution was scanned in the SHIMADZU UV Spectrophotometer, model 1700 from 200 to $400 \mathrm{~nm}$ using Milli-Q water as blank and $\lambda_{\max }$ was determined.

\section{Preparation of calibration curve of diclofenac sodium}

$0.5 \mathrm{ml}, 1 \mathrm{ml}, 1.5 \mathrm{ml}, 2.0 \mathrm{ml} 2.5 \mathrm{ml}$, and $3.0 \mathrm{ml}$ was taken from standard stock solution and diluted upto $50 \mathrm{ml}$ by adding Milli-Q water, the final concentration of these solution were $10 \mu \mathrm{g} / \mathrm{ml}, 20 \mu \mathrm{g} / \mathrm{ml}, 30$ $\mu \mathrm{g} / \mathrm{ml}, 40 \mu \mathrm{g} / \mathrm{ml}, 50 \mu \mathrm{g} / \mathrm{ml}$ and $60 \mu \mathrm{g} / \mathrm{ml}$ respectively. Absorbances of all solutions were measured at $275.8 \mathrm{~nm}$. The observations were recorded and graphically presented (Table 1, Figures 2 and 3) [20].

\section{Preparation of simulated buffer medium}

To prepare Phosphate Buffer ( $\mathrm{pH}$ 6.8) $11.45 \mathrm{~g}$ of $\mathrm{KH}_{2} \mathrm{PO}_{4}$ and 28.8 $\mathrm{g}$ of $\mathrm{Na}_{2} \mathrm{HPO}_{4}$ was dissolved in water and volume was adjusted by 1000 $\mathrm{ml}[21]$.

\section{In vitro dissolution study}

In vitro dissolution was performed by using US Pharmacopoeia dissolution type II apparatus at $37 \pm 0.5^{\circ} \mathrm{C}$ with a rotation speed $50 \mathrm{rpm} /$ $\mathrm{min}$ and $900 \mathrm{ml}$ of dissolution medium in per vessel used. The tablets

\begin{tabular}{|c|c|}
\hline Conc. $(\boldsymbol{\mu g} / \mathbf{m l})$ & Abs. $\left(\boldsymbol{\lambda}_{\max }\right)$ \\
\hline 0 & 0 \\
\hline 10 & 0.319 \\
\hline 20 & 0.64 \\
\hline 30 & 0.973 \\
\hline 40 & 1.313 \\
\hline 50 & 1.601 \\
\hline 60 & 1.945 \\
\hline
\end{tabular}

Table 1: Data of the calibration curve of Diclofenac Sodium.

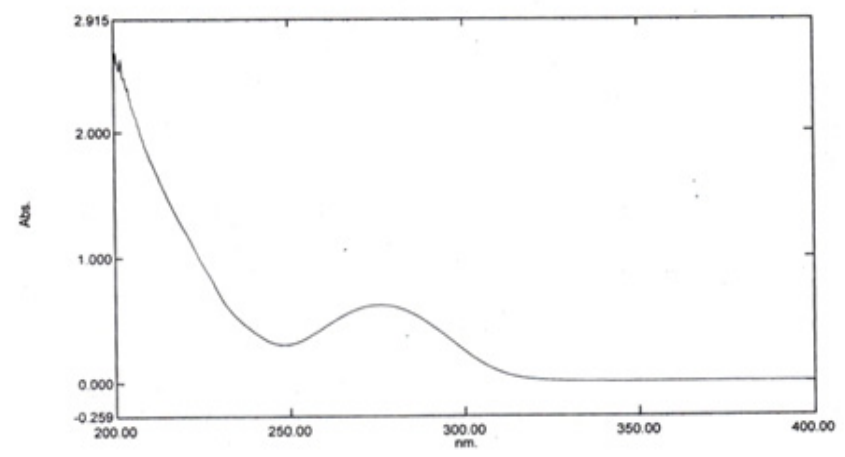

Figure 2: Determination of $\lambda_{\max }$

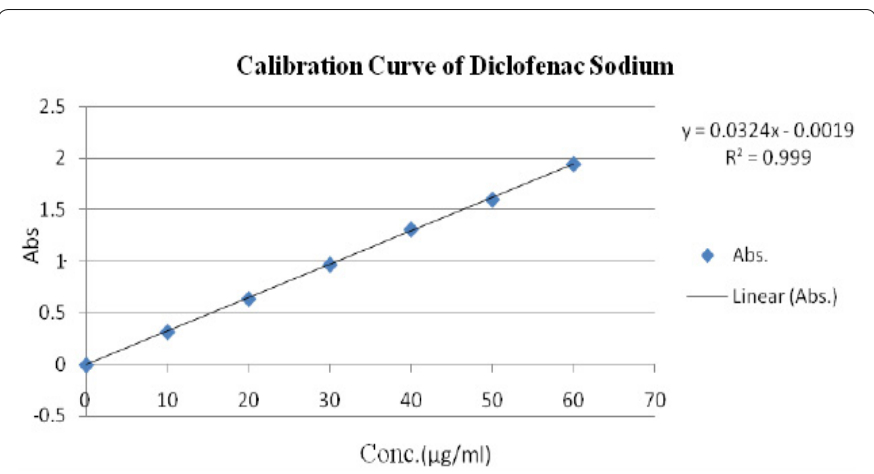

Figure 3: Calibration curve of Diclofenac Sodium.

were immersed into a phosphate buffer $(\mathrm{pH}=6.8)$ for $1 \mathrm{~h}$. The sample solutions were analyzed for Diclofenac Sodium by UV absorbance at $275.8 \mathrm{~nm}$ by using a UV spectrophotometer [22].

Thus, for each sub sample of four tablets tested simultaneously, every individual tablet result was identified with a particular vessel and position. At every $15 \mathrm{~min}$ interval sample $(5 \mathrm{ml})$ of the solution was withdrawn from the vessel and immediately replaced with equal volumes of dissolution medium. The withdrawn samples $(5 \mathrm{ml})$ were then filtered and diluted, analyzed at $275.8 \mathrm{~nm}$ for Diclofenac Sodium by UV spectrophotometer. The amounts of drug present in the samples were calculated from calibration curve of standard Diclofenac Sodium.

\section{Hardness}

Ten tablets from each batch were selected and hardness was measured using Veego hardness tester to find the average tablet hardness or crushing strength [23]. Hardness depends on pressure applied, dwell time and nature of formulation was shown in Table 2 [24].

\section{Results}

Determination of $\lambda$ max: Figure 2. 
Calibration Curve of Diclofenac Sodium: The solution of Diclofenac Sodium in the concentration of $10-60 \mu \mathrm{g} / \mathrm{ml}$ was prepared. The observations were presented in the following table and figure.

\section{In vitro dissolution test}

Commercially available four brands of diclofenac sodium tablets were studied for their in vitro dissolution behaviour in using phosphate buffer ( $\mathrm{pH}$ 6.8) dissolution medium. Release rate of the samples were determined for $1 \mathrm{~h}$. In dissolution media, all the brands were fulfil the USP in vitro dissolution specification i.e., $80 \%$ drug release within 40 min in simulated phosphate buffer medium. Results of sample D01 to D04 were presented in below.

\section{Discussion}

From the above experiment it is found that the hardness of two samples D01 and D03 is 13 and 11.62 due to their increased hardness their release time became slower than the other two samples. The potency and dissolution of four marketed samples is within the BP and
USP specifications. The potency determined were $99.30 \%, 103.38 \%$, $98.22 \%$ and $102.16 \%$ respectively. Hardness and in vitro dissolution of the above four brands of Diclofenac Sodium tablets were also studied and reported in the paper. From all of the studies it seems that the samples were collected complies with the BP and USP requirements. The rate of drug release controlled by increase or decrease in the drug solubility and concentration of drug in matrix system and also dissolution rate depends on the surrounding medium. To understand the release kinetics of tablet matrix in dissolution corresponding data were canvassed by various dissolution kinetics models such as Zero Order, First Order, Higuchi, and Hixon-Crowell etc. According to percent release vs. time (Figure 4), the log of release percent release vs. time (Figure 5), percent release vs. square root time (Figure 6) and cube root percent of release vs. time respectively (Figure 7). After $1 \mathrm{~h}$ dissolution release of DO1, D02, D03, and D04 are 94.16\%, 93.97\%, 96.94\% and $98.5 \%$ respectively (Tables $3-5$ ).

\section{Conclusion}

The results of our preliminary studies indicated in vitro dissolution

\begin{tabular}{|c|c|c|c|c|c|c|c|c|c|c|c|}
\hline \multirow[t]{2}{*}{ Hardness (kg) } & \multicolumn{10}{|c|}{ Serial Number } & \multirow[t]{2}{*}{ Average } \\
\hline & $\mathbf{a}$ & b & c & d & e & $f$ & g & h & $\mathbf{i}$ & $\mathbf{j}$ & \\
\hline Sample D01 & 14 & 13.5 & 14 & 13 & 12.5 & 11.5 & 13 & 13 & 12.8 & 13.2 & 13 \\
\hline Sample D02 & 7.0 & 7.2 & 7.2 & 7.0 & 7.0 & 7.4 & 7.8 & 7.6 & 8 & 7.4 & 6.66 \\
\hline Sample D03 & 14 & 13.5 & 14 & 13 & 12.5 & 11.5 & 13 & 13 & 12.8 & 13.2 & 11.62 \\
\hline SampleD04 & 8.8 & 7.8 & 8.0 & 6.8 & 7.0 & 7.8 & 7.4 & 7.2 & 7.8 & 7.8 & 7.64 \\
\hline
\end{tabular}

Table 2: Hardness test of Diclofenac Sodium: Commercially available four brands (10 tablets for each brand according to BP) of diclofenac sodium tablets were taken to check the hardness parameter are shown below.

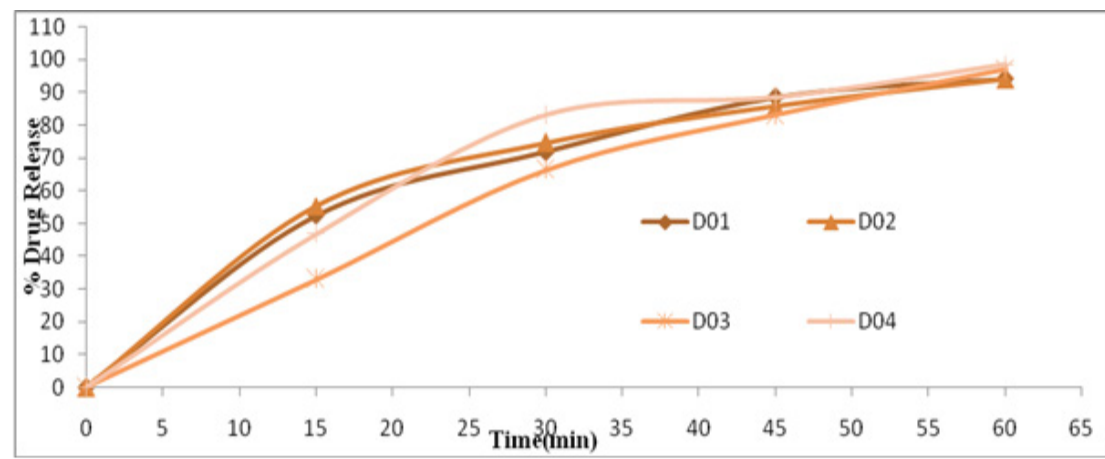

Figure 4: Zero order plots to ascertain release kinetics of Diclofenac Sodium samples.

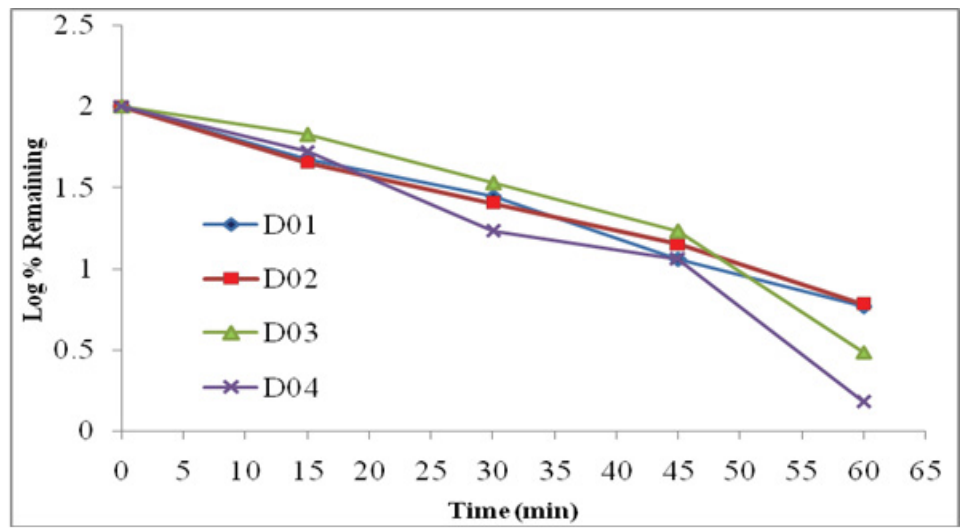

Figure 5: First order plots to ascertain release kinetics of Diclofenac Sodium samples. 
Citation: Sultana T, Sohel MD, Kawsar MH, Banoo R (2017) In Vitro Dissolution Study and Assay of Diclofenac Sodium from Marketed Solid Dosage form in Bangladesh. J Bioanal Biomed 9: 118-122. doi:10.4172/1948-593X.1000164

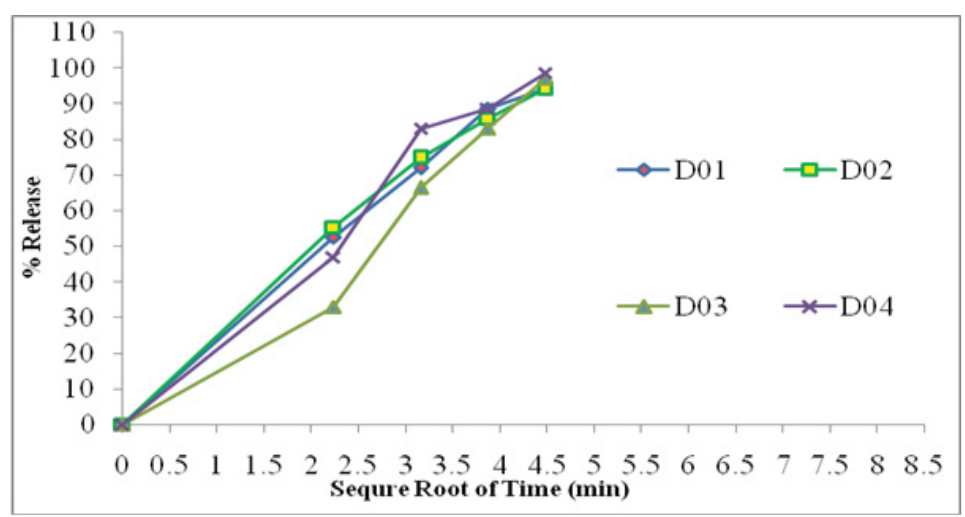

Figure 6: Higuchi plots to ascertain release kinetics of Diclofenac Sodium samples.

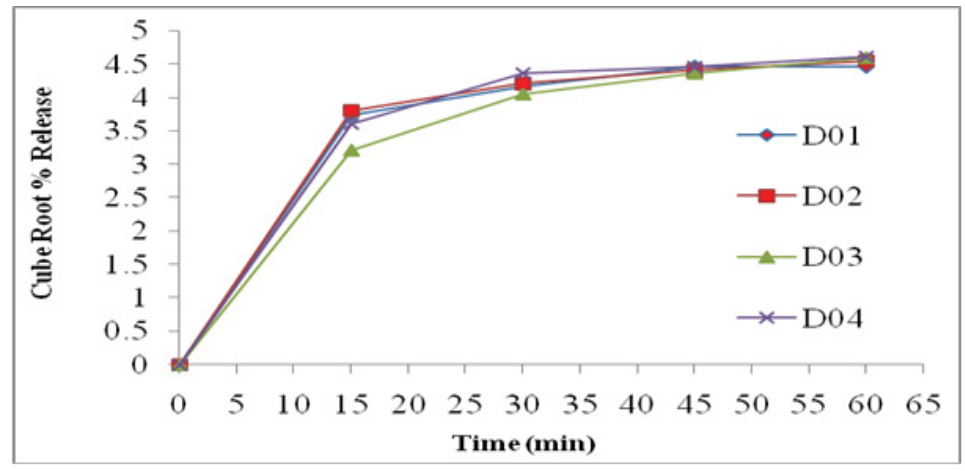

Figure 7: Hixon-Crowell plots to ascertain release kinetics of Diclofenac Sodium samples.

\begin{tabular}{|c|c|c|c|c|c|c|c|c|c|}
\hline \multirow{2}{*}{$\begin{array}{c}\text { Sample Code } \\
\text { D01 }\end{array}$} & \multirow{2}{*}{$\begin{array}{c}\text { Sample No. } \\
1 \mathrm{a} \\
1 \mathrm{~b} \\
\end{array}$} & \multicolumn{3}{|c|}{ Absorbance } & \multirow{2}{*}{$\begin{array}{c}\begin{array}{c}\text { Average } \\
\text { Absorbance }\end{array} \\
0.964 \\
1.606 \\
\end{array}$} & \multirow{2}{*}{$\begin{array}{c}\begin{array}{c}\text { Conc. from standard } \\
\text { curve }(\mu \mathrm{g} / \mathrm{ml})\end{array} \\
29.81 \\
49.62 \\
\end{array}$} & \multirow{2}{*}{$\begin{array}{c}\begin{array}{c}\text { Potency } \\
\text { calculated }(\mathbf{m g})\end{array} \\
49.68 \\
49.62 \\
\end{array}$} & \multirow{2}{*}{$\begin{array}{c}\begin{array}{c}\text { \% potency } \\
\text { determined }\end{array} \\
99.36 \\
99.25 \\
\end{array}$} & \multirow{2}{*}{$\begin{array}{c}\begin{array}{c}\text { Average } \% \\
\text { potency }\end{array} \\
99.30\end{array}$} \\
\hline & & $\begin{array}{l}0.970 \\
1.611\end{array}$ & $\begin{array}{l}0.954 \\
1.572\end{array}$ & $\begin{array}{l}0.969 \\
1.637\end{array}$ & & & & & \\
\hline D02 & $\begin{array}{l}2 a \\
2 b\end{array}$ & $\begin{array}{l}0.949 \\
1.668 \\
\end{array}$ & $\begin{array}{l}1.018 \\
1.691 \\
\end{array}$ & $\begin{array}{l}1.025 \\
1.691 \\
\end{array}$ & $\begin{array}{l}0.997 \\
1.683 \\
\end{array}$ & $\begin{array}{c}30.83 \\
52.0\end{array}$ & $\begin{array}{c}51.38 \\
52.0\end{array}$ & $\begin{array}{c}102.76 \\
104.0 \\
\end{array}$ & 103.38 \\
\hline D03 & $\begin{array}{l}3 a \\
3 b\end{array}$ & $\begin{array}{l}0.948 \\
1.594 \\
\end{array}$ & $\begin{array}{l}0.972 \\
1.554 \\
\end{array}$ & $\begin{array}{l}0.956 \\
1.589 \\
\end{array}$ & $\begin{array}{l}0.959 \\
1.579 \\
\end{array}$ & $\begin{array}{l}29.65 \\
48.79 \\
\end{array}$ & $\begin{array}{l}49.42 \\
48.80 \\
\end{array}$ & $\begin{array}{c}98.84 \\
97.6\end{array}$ & 98.22 \\
\hline D04 & $\begin{array}{l}4 a \\
4 b\end{array}$ & $\begin{array}{l}0.991 \\
1.661\end{array}$ & $\begin{array}{l}0.979 \\
1.668\end{array}$ & $\begin{array}{l}0.978 \\
1.672\end{array}$ & $\begin{array}{l}0.983 \\
1.667\end{array}$ & $\begin{array}{l}30.39 \\
51.50\end{array}$ & $\begin{array}{l}50.66 \\
51.50\end{array}$ & $\begin{array}{c}101.32 \\
103.0\end{array}$ & 102.16 \\
\hline
\end{tabular}

Table 3: Data for determination of potency of Diclofenac Sodium from solid dosage form.

\begin{tabular}{|c|c|c|c|c|}
\hline \multirow{2}{*}{ Time (min) } & \multicolumn{4}{|c|}{ \% of drug release } \\
\cline { 2 - 5 } & D01 & D02 & D03 & D04 \\
\hline $\mathbf{0}$ & 0 & 0 & 0 & 0 \\
\hline $\mathbf{1 5}$ & 52.5 & 55.28 & 33.05 & 46.94 \\
\hline $\mathbf{3 0}$ & 71.94 & 74.72 & 66.39 & 83.05 \\
\hline $\mathbf{4 5}$ & 88.61 & 85.83 & 83.06 & 88.61 \\
\hline $\mathbf{6 0}$ & 94.16 & 93.97 & 96.94 & 98.5 \\
\hline
\end{tabular}

Table 4: In vitro dissolution of four marketed diclofenac sodium coded as D01, D02, D03 and D04.

study and assay of Diclofenac Sodium from marketed solid dosage form in Bangladesh meet official specification due to the maintain of quality of the products.

\section{Acknowledgement}

The authors wish to thank, Pharmaceutical Technology Laboratory, Department of Pharmacy, State University of Bangladesh for providing laboratory facilities to carry out the experiments.

\begin{tabular}{|c|c|c|c|}
\hline S. No. & Hardness $\mathbf{( k g )}$ & Potency (\%) & \% release after $\mathbf{1 ~ h}$ \\
\hline Sample D01 & 13.0 & $99.30 \%$ & 94.16 \\
\hline Sample D02 & 6.66 & $103.38 \%$ & 102.5 \\
\hline Sample D03 & 11.62 & $98.22 \%$ & 96.17 \\
\hline Sample D04 & 7.64 & $102.16 \%$ & 98.5 \\
\hline
\end{tabular}

Table 5: Hardness, \% potency and \% release (after $1 \mathrm{~h}$ ) of Diclofenac Sodium.

\section{References}

1. Nayak AK (2010) Thermodynamic study of the diclofenac sodium solubility in various oils. Chemistry 19: 121-128.

2. Timmakondu S, Prabu SL, Satyam T (2011) In-vitro studies of diclofenac sodium controlled-release dosage from biopolymeric hydrophilic matrices. Ars Pharm 52: 20-24.

3. Giri TK, Parveen N, Thakur D, Tripathi DK (2012) In vitro Evaluation of Commercially Available Enteric Coated Tablet Containing Diclofenac Sodium. IJRPBS 3: 875-881.

4. UI-Hassan SS, Yunus SH, Latif A (2010) Study and Improvement of Methods 
Citation: Sultana T, Sohel MD, Kawsar MH, Banoo R (2017) In Vitro Dissolution Study and Assay of Diclofenac Sodium from Marketed Solid Dosage form in Bangladesh. J Bioanal Biomed 9: 118-122. doi:10.4172/1948-593X.1000164

for the Determination of Diclofenac Sodium in Pharmaceutical Preparations. Pak J Pharm 23: 7-10.

5. Chandra R, Singh S, Sharma K, Alam N, Kumar S (2013) Quantity based quality estimation of diclofenac sodium by reversed phase-high performance liquid chromatography separation method from formulated tablets. IJCP 4: 1.

6. Ahmed NR (2011) High performance liquid chromatographic method for the determination of diclofenac sodium in pharmaceutical preparations and in environmental samples. Irq Nat J Chem 44: 467-473.

7. Todd PA, Sorkin EM (1988) Diclofenac sodium. A reappraisal of its pharmacodynamic and pharmacokinetic properties, and therapeutic efficacy. Drugs 35: 244-285.

8. Nyol S, Gupta MM (2013) Immediate Drug Release Dosage Form: A Review. JDDT 3: 155-161.

9. Perttunen K, Kalso E, Heinonen J, Salo J (1992) IV diclofenac in post thoracotomy pain. Br J Anaesth 68: 474-480.

10. Mather LE (1992) Do the pharmacodynamics of the nonsteroidal antiinflammatory drugs suggest a role in the management of postoperative pain Drugs 44: 1-13.

11. Morrow BC, Bunting H, Milligan KR (1993) A comparison of diclofenac and ketorolac for postoperative analgesia following daycase arthroscopy of the knee joint. Anaesthesia 48: 585-587.

12. Roelofse JA, van der Bijl P, Joubert JJ (1993) An open comparative study of the analgesic effects of tenoxicam and diclofenac sodium after third molar surgery. Anesth Pain Control Dent 2: 217-222.

13. Tonussi CR, Ferreira SH (1994) Mechanism of diclofenac analgesia: direct blockade of inflammatory sensitization. Eur J Pharmacol 251: 173-179.

14. Gelgor L, Cartmell S, Mitchell D (1992) Intracerebroventricular microinjections of non-steroidal anti-inflammatory drugs abolish reperfusion hyperalgesia in the rat's tail. Pain 50: 323-329.
15. Björkman RL, Hedner T, Hallman KM, Henning M, Hedner J (1992) Localization of the central antinociceptive effects of diclofenac in the rat. Brain Res 590 66-73.

16. Björkman R, Hedner J, Hedner T, Henning M (1990) Central, naloxonereversible antinociception by diclofenac in the rat. Naunyn Schmiedebergs Arch Pharmacol 342: 171-176.

17. Bjorkman R (1995) Central antinociceptive effects of non-steroidal antiinflammatory drugs and paracetamol. Experimental studies in the rat. Acta Anaesthesiol Scand 103: 1-44.

18. Molly M (2010) Drug utilization of non-steroidal anti-inflammatory drugs at community pharmacies in south india. IJCP 3: 15-19.

19. Khan MA, Khan J, Razvi N (2011) Physicochemical equivalence of different brands of diclofenic sodium sustains release tablets available in local market. IRJP 2: 81-84

20. Khaskheli AR, Sirajuddin, Abro K, Sherazi STH, Mahesar SA, et al. (2009) Simpler and faster spectrophotometric determination of diclofenac sodium in tablets, serum and urine samples. Pak J Anal Environ Chem 10: 53-58.

21. British Pharmacopoeia Commission (2005) British Pharmacopoeia. Stationery Office, London 4: 134.

22. Bravo SA, Lamas MC, Salamón CJ (2002) In-vitro studies of diclofenac sodium controlled-release from biopolymeric hydrophilic matrices. J Pharm Pharm Sci 5: 213-219.

23. Bharathi A (2011) Formulation and in-vitro evaluation of diclofenac sodium sustained release matrix tablets using melt granulation technique. Int $\mathrm{J}$ Res Pharmaceut Biomed Sci 2: 788-808.

24. British Pharmacopoeia (1998) The Pharmaceutical press, Her Majesty's Stationary office, London pp: 379, 969 and 1242. 